\title{
Environmental radioactivity measurement in soils of an abandoned potash deposit at Holle, Republic of Congo
}

\author{
Russel Rolphe Caroll Moubakou Diahou ${ }^{1,2,4}$; Hamid Bounouira3; Guy Blanchard Dallou ${ }^{1,}$; Rajâa \\ Cherkaoui El Moursli ${ }^{4}$ and Clobite Bouka Biona ${ }^{1}$ \\ ${ }^{1}$ Marien Ngouabi University, Faculty of Sciences and Techniques, BP 69 Brazzaville, Congo. \\ ${ }^{2}$ Institut National de Recherche en Sciences Exactes et Naturelles (IRSEN), P.O Box 2400 Brazzaville, Congo, \\ Laboratoire de Physique Nucléaire et Applications (LPNA) \\ ${ }^{3}$ Centre National de l'Energie, des Sciences et des Techniques Nucléaires (CNESTEN)-Maroc, Laboratoires \\ d'Analyses Elémentaires et Radiométrique (LAER), Division Exploitation des Laboratoires (DEL), \\ ${ }^{4}$ Mohammed V University-Agdal, Faculty of Sciences, Laboratory of Nuclear Physics, road 4 Ibn Battouta, B.P. 1014 \\ RP, Rabat, Morocco.
}

\begin{abstract}
The main objective of the present study was to assess natural radioactivity level from soils of an abandoned potash mine and its surroundings at Holle locality in Hinda district, the Republic of Congo. Samples were analyzed using an HPGe gamma spectrometer. Activity concentration values obtained varied from $21.01 \pm 6.47$ to $117.3 \pm 2.69 \mathrm{~Bq} / \mathrm{kg}$ with a mean value of $46.15 \pm 4.69 \mathrm{~Bq} / \mathrm{kg}$ of ${ }^{40} \mathrm{~K}$; that of ${ }^{238} \mathrm{U}$ varied from $17.36 \pm 10.74$ to $40.04 \pm 8.58 \mathrm{~Bq} / \mathrm{kg}$ with a mean value of $25.14 \pm 10.06 \mathrm{~Bq} / \mathrm{k}$, while that of ${ }^{232} \mathrm{Th}$ varied from $8.68 \pm 3.7$ to $27.33 \pm 2.69 \mathrm{~Bq} / \mathrm{kg}$ with a mean value of $18.16 \pm 2.94 \mathrm{~Bq} / \mathrm{kg}$. Mean activity concentration values obtained for ${ }^{238} \mathrm{U},{ }^{232} \mathrm{Th}$ and ${ }^{40} \mathrm{~K}$ were relatively low compared to the world average values. Radiological hazard indices associated were also calculated and found to be under recommended limits. Results pointed out that radioactivity level in the region was relatively low. Consequently, soils of the surrounding abandoned potash mine can be used for buildings construction.
\end{abstract}

Keywords: Natural radionuclides, Radiological hazards, Soil, Holle potash deposit, gamma spectrometry

\section{Introduction}

The Republic of Congo is one of the richest subsoil countries in the world. The mining of these resources by foreign companies is accompanied by a glaring absence of accompanying measurement in the field of public health and radiation protection for the surrounding populations. This disregard of public authorities could lead to the development of diseases in the region such as a cancer. Most of these exploited mines in the Republic of Congo are unfortunately abandoned and left in plain sight in the country, such is the case of Holle potash mine, also called Saint-Paul mine.

Works on radioactivity measurement have never been conducted in soils around mine sites in the Republic of Congo. The level of contamination and the daily doses received by the surrounding population, also visitors are unknown and uncontrolled in the region. Then, the Republic of Congo does not have standards or guidelines for the maximum level of radioactivity in soils.

However, soils from abandoned mine sites have been the subject of many studies worldwide: [1-6]
It is also disturbing to note that this abandoned mine is actually turned into economic site by some of the villagers, who engaged activities such as the selling of those potash-salts to those who made salted-fish, to farmers, etc. It is also consumed by the surrounding populations. Herdsmen considered it like a relaxation place, where they spend most of their time to feed their cattle. It is important to note that, this is the first study of measurement of terrestrial gamma radiation doses from soil in the region. So, it is intended that our results would form a baseline scientific data of external terrestrial gamma-radiation doses and an estimate of radiation exposure to public from soils of the study area.

The present study was carried out to determine the activity concentrations of natural radionuclides ${ }^{40} \mathrm{~K},{ }^{238} \mathrm{U}$ and ${ }^{232} \mathrm{Th}$ in soil samples at Holle locality in Hinda district in the Republic of Congo. The results are also compared with those of other regions worldwide and are used to assess the potential radiological hazards associated with these soils by estimating the external hazard index $\left(\mathrm{H}_{\mathrm{ex}}\right)$, internal hazard index $\left(\mathrm{H}_{\mathrm{in}}\right)$, representative level index $\left(\mathrm{I}_{\mathrm{Yr}}\right)$, activity index $(\mathrm{I})$, radium equivalent activity $\left(R a_{e q}\right)$, absorbed dose rates in air $\left(D_{R}\right)$

\footnotetext{
*Corresponding author: foxrussellrolph@gmail.com
} 
and the annual outdoor effective dose equivalent rates (E).

\section{Material and Method}

\section{1 Study area}

Hinda district is located on latitude $4^{\circ} 36^{\prime} 48^{\prime \prime} \mathrm{S}$ and longitude $12^{\circ} 02^{\prime} 37^{\prime \prime} \mathrm{E}$. It is about $34 \mathrm{~m}$ above sea level and has an approximate population of 32995. It is closed to the Kouilou department (Figure 1) and its climate is subject to the influence of the Atlantic Ocean. The great dry season begins in May and ends in mid-September in the coastal zone. The short dry season is hardly felt there in December-January. The great rainy season covers the months of February, March, April and part of May. The short rainy season only lasts two months (October, November). The drop in temperatures in the dry season is more pronounced on the coast than in land beyond Mayombe $\left(20^{\circ} \mathrm{C}\right)$. The region is geologically characterized by white quartzite with schistose intercalation.

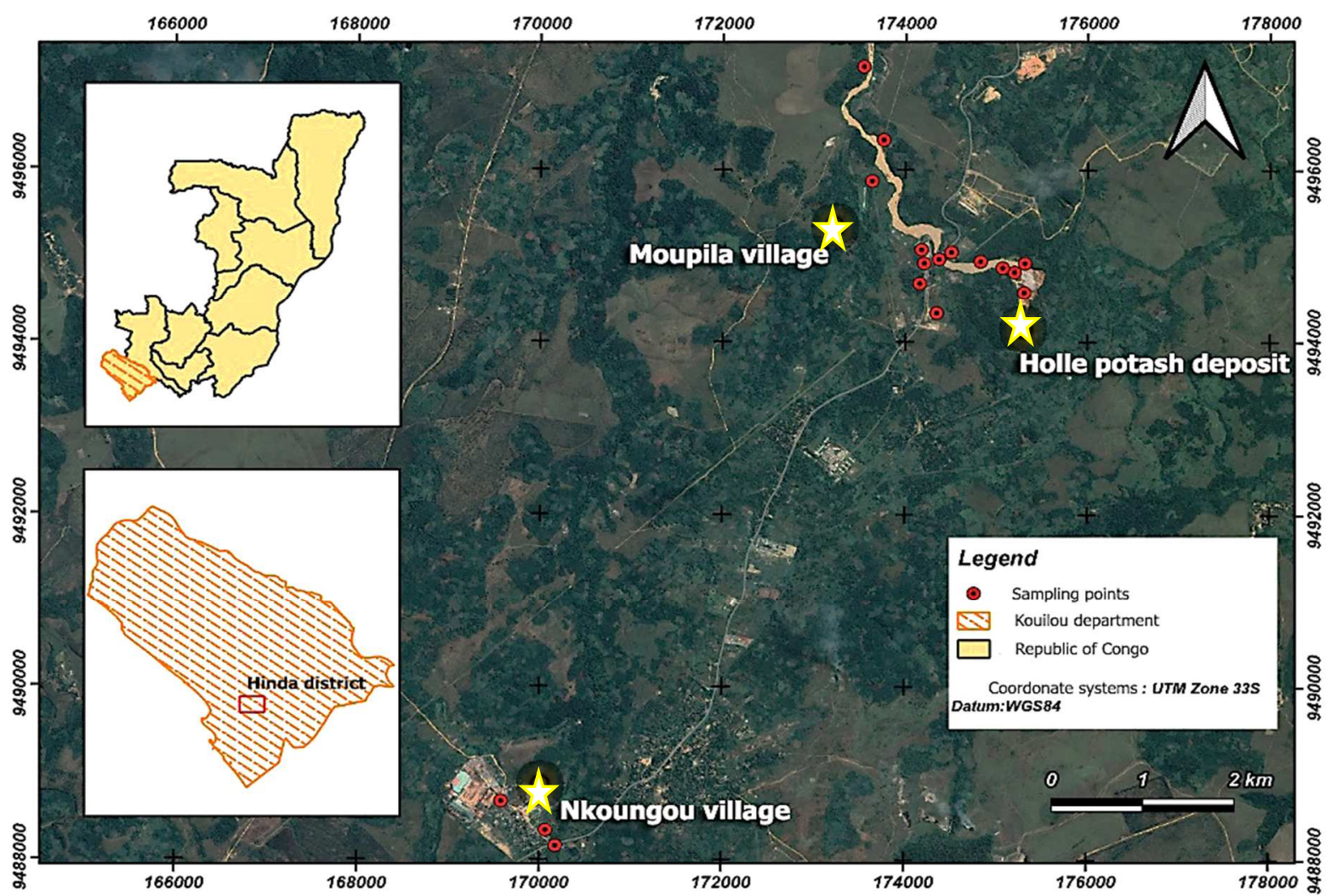

Fig. 1. Study area : Sampling point in Hinda district, Kouilou

The abandoned potash mine is located at Holle locality, in the district of Hinda. This mine was mined in 1970 and halted when the mine flooded in 1977s. Holle potash mine is an underground mine where the surface is covered by gem salts (Figure 2).

\footnotetext{
* Corresponding author: foxrussellrolph@gmail.com
} 


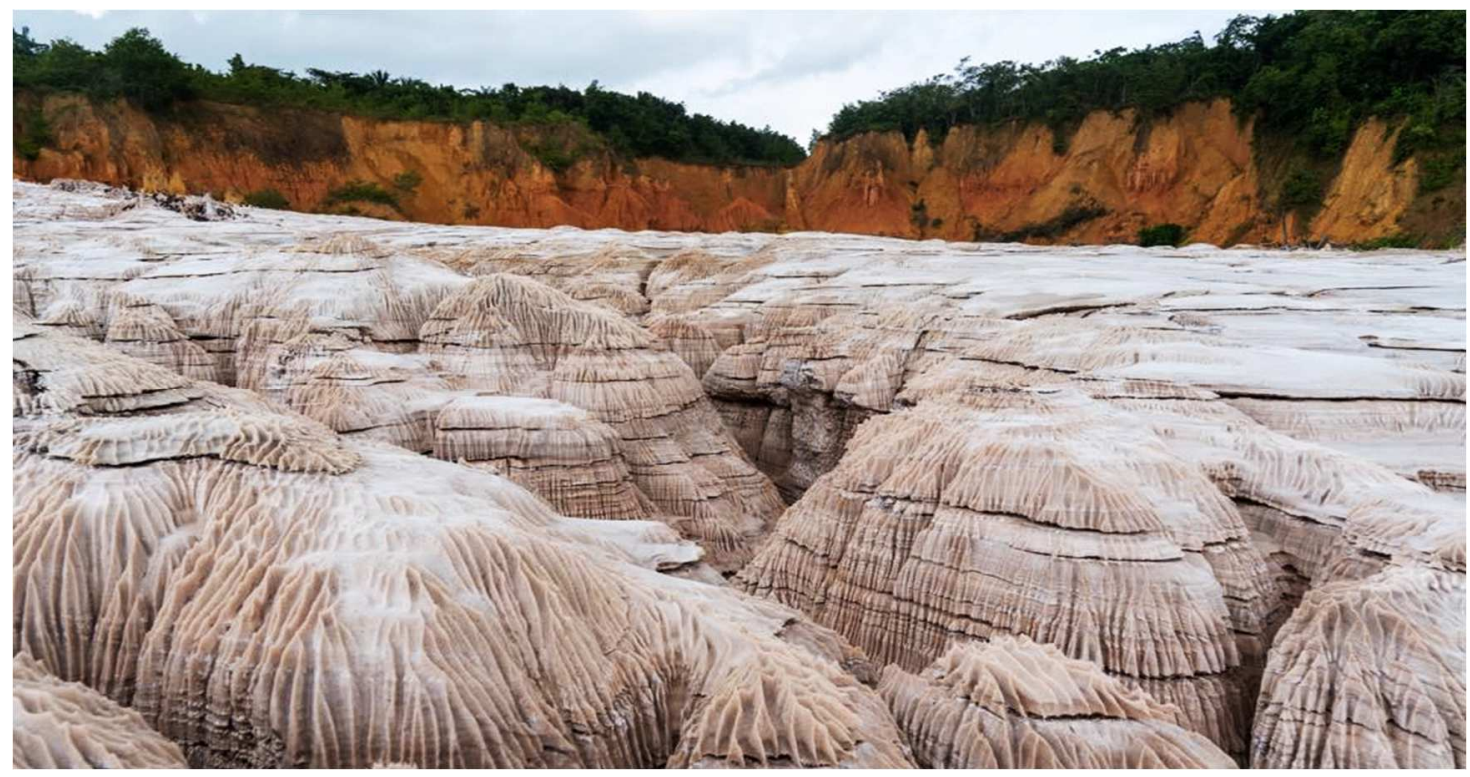

Fig. 2. Holle potash deposit at Holle locality in Hinda district, Kouilou Department, Republic of Congo.

\section{2 Sampling and conditioning}

A total of seventeen (17) samples were collected: Four (04) in Holle potash deposit, nine (09) in Moupila village where people lives and three (03) at Nkoungou village (considered as a non-contaminated area: reference) at about $10 \mathrm{~km}$ of Holle potash deposit.

Samples were collected manually and randomly. Each sample were collected at a maximum depth of $5 \mathrm{~cm}$, with a total fresh mass of about $1 \mathrm{~kg}$. The soil samples were stored in sealed plastic containers, carefully labeled and taken to the Elemental and Radiometric Analysis

\section{3 Gamma Spectrometry analysis and measurement}

The gamma ray spectrometry analysis was carried out at the Elementary and Radiometric Analysis Laboratory (LAER) in CNESTEN, Morocco. This was done using a Canberra coaxial HPGe detector having a relative efficiency of $30 \%$ with resolutions of $1.85 \mathrm{Kev}$ at the 1.33 $\mathrm{MeV}$ gamma line of the ${ }^{60} \mathrm{Co}$, enclosed in a lead shield. The complete electronic instrumentation was connected to a PC-based multichannel analyzer for gamma spectrum evaluation.

$0.5 \mathrm{~g}$ of a standard calibration source was deducted in 5 $\mathrm{mL}$ flame-sealed ampoule and injected in a 1-liter filled Marinelli beaker containing water. The source was homogeneously distributed in the solution and use for the calibration of the system. The detector calibration and the sample measurement carried out in the same geometry with the same counting time.

\footnotetext{
Corresponding author: foxrussellrolph@gmail.com
}

Laboratory (LAER) in National Center of Energy, Sciences and Nuclear Techniques (CNESTEN), Morocco. In laboratory, after removal of big particles, the samples were oven-dried at $105^{\circ} \mathrm{C}$ during $24 \mathrm{~h}$, then ground and sieved. Each sample was weighed, homogenized and conditioned in 11 Marinelli beakers completely sealed during at least 1 month to avoid radon escape. This ensures secular equilibrium between the heads of the uranium and thorium decay series and their short-lived progenies [7] before gamma counting.

Each sample was counted for a period of $86400 \mathrm{~s} \mathrm{(24h)} \mathrm{to}$ achieve the statistical error of counting of less than $1 \%$. Background spectrum acquisition was measured at $150000 \mathrm{~s}$.

The energy calibration of the system was done using a standard mixture source of gamma-emitting isotopes: ${ }^{241} \mathrm{Am},{ }^{109} \mathrm{Cd},{ }^{57} \mathrm{Co},{ }^{123 m} \mathrm{Te},{ }^{51} \mathrm{Cr},{ }^{113} \mathrm{Sn},{ }^{85} \mathrm{Sr},{ }^{137} \mathrm{Cs},{ }^{88} \mathrm{Y}$, ${ }^{60} \mathrm{Co}$, supplied by Ecker \& Ziegler Isotope Products.

${ }^{238} \mathrm{U}$ was determined through its daughter radionuclides of ${ }^{234} \mathrm{Th}(63,38 \mathrm{kev})$ and ${ }^{234 \mathrm{~m}} \mathrm{~Pa}(1001 \mathrm{kev}) .{ }^{226} \mathrm{Ra}$ was obtained from ${ }^{214} \mathrm{~Pb}(295.2 \mathrm{kev}$ and $351.9 \mathrm{kev})$ and ${ }^{214} \mathrm{Bi}$ (609.3, $1764.5 \mathrm{kev})$. For ${ }^{232} \mathrm{Th}$ following radionuclides were used ${ }^{208} \mathrm{Tl}(583.2 \mathrm{Kev}),{ }^{228} \mathrm{Ac}(338.3 \mathrm{kev}, 911.2 \mathrm{kev})$ and ${ }^{212} \mathrm{~Pb}(238.6 \mathrm{kev})$. Finally, the activity concentration of ${ }^{40} \mathrm{~K}$ was determined directly through its line $1460.8 \mathrm{kev}$ [8]. 
The concentrations of gamma-emitting isotopes were determined using the following relation:

$$
\mathrm{A}=\frac{\frac{\mathrm{N}}{\mathrm{Tc}}-\frac{\mathrm{Nb}}{\mathrm{Tb}}}{\mathrm{mI}_{\gamma} \varepsilon_{Y}}
$$

Where $\mathrm{A}(\mathrm{Bq} / \mathrm{kg})$ is activity concentration of the considered radioisotope, $\mathrm{N}$ and $\mathrm{N}_{\mathrm{b}}$ are net counts of samples and background respectively, $\mathrm{T}_{\mathrm{c}}$ and $\mathrm{T}_{\mathrm{b}}$ are acquisition times of samples and background respectively, $\mathrm{m}(\mathrm{kg})$ is the mass of the sample, $\varepsilon_{\gamma}$ is the absolute gamma peak detection efficiency and $I_{Y}$ is emission probability of the corresponding gamma-ray energy.

However, uncertainty of activity was calculated by the following equation:

$\frac{\sigma_{\mathrm{A}}^{2}}{\mathrm{~A}^{2}}=\frac{\sigma_{\mathrm{N}}^{2}}{\mathrm{~N}^{2}}+\frac{\sigma_{\mathrm{m}}^{2}}{\mathrm{~m}^{2}}+\frac{\sigma_{\varepsilon}^{2}}{\varepsilon^{2}}+\frac{\sigma_{\mathrm{Nb}}^{2}}{\mathrm{Nb}^{2}}$

Where $\sigma_{A}^{2}, \sigma_{N}^{2}, \sigma_{\varepsilon}^{2}, \sigma_{N b}^{2}, \sigma_{m}^{2}$ are standard deviation of A, $\mathrm{N}, \mathcal{\varepsilon}, \mathrm{N}_{\mathrm{b}}$ and $\mathrm{m}$ respectively.

\section{4 Radiation hazard parameters}

In order to assess the radiation hazard associated with natural radionuclides $\left({ }^{40} \mathrm{~K},{ }^{238} \mathrm{U}\right.$ and $\left.{ }^{232} \mathrm{Th}\right)$ in the soils of Holle potash deposit, the following radiological parameters were calculated: the absorbed dose rates in air $\left(D_{R}\right)$, representative level index $\left(I_{Y_{r}}\right)$, activity index $(I)$, radium equivalent activity $\left(\mathrm{Ra}_{\mathrm{eq}}\right)$, and the annual outdoor effective dose equivalent rates $(\mathrm{E})$.

\section{Results}

\section{1 Measurement of ${ }^{238} \mathrm{U},{ }^{232} \mathrm{Th}$ and ${ }^{40} \mathrm{~K}$}

Results are displayed in Table 1. The activity concentrations of ${ }^{40} \mathrm{~K},{ }^{238} \mathrm{U}$ and ${ }^{232} \mathrm{Th}$ varied from $21.01 \pm$ 6.47 to $117.3 \pm 2.69 \mathrm{~Bq} / \mathrm{kg}, 17.36 \pm 10.74$ to $40.04 \pm 8.58$ $\mathrm{Bq} / \mathrm{kg}$ and $8.68 \pm 3.7$ to $27.33 \pm 2.69 \mathrm{~Bq} / \mathrm{kg}$ respectively. The mean activity concentrations of ${ }^{40} \mathrm{~K},{ }^{238} \mathrm{U}$ and ${ }^{232} \mathrm{Th}$ in the soil samples were observed to be, respectively relatively low compared to the world average values [9].

Table 1. Activity concentrations $(\mathrm{Bq} / \mathrm{kg})$ of different radionuclides in the soil samples.

\begin{tabular}{|c|c|c|c|c|}
\hline Sample & Location & ${ }^{238} \mathrm{U}$ & ${ }^{232} \mathrm{Th}$ & ${ }^{40} \mathrm{~K}$ \\
\hline Prlvt 1 & Holle deposit & $17.36 \pm 10.74$ & $8.68 \pm 3.7$ & $20.89 \pm 5.58$ \\
\hline Prlvt 2 & Holle deposit & $24.04 \pm 6.8$ & $22.79 \pm 2.64$ & $33.17 \pm 4.69$ \\
\hline Prlvt 3 & Holle deposit & $28.64 \pm 11.13$ & $22.20 \pm 2.69$ & $117.3 \pm 2.69$ \\
\hline Prlvt 4 & Holle deposit & $33.74 \pm 12.93$ & $21.78 \pm 2.78$ & $97.03 \pm 2.94$ \\
\hline Prlvt 5 & Moupila Village & $24.53 \pm 6.44$ & $22.33 \pm 2.69$ & $31.1 \pm 5.2$ \\
\hline Prlvt 6 & Moupila Village & $18.91 \pm 11.24$ & $15.95 \pm 2.97$ & $27.4 \pm 5.25$ \\
\hline Prlvt 7 & Moupila Village & $27.9 \pm 11.88$ & $17.01 \pm 2.93$ & $25.23 \pm 5.25$ \\
\hline Prlvt 8 & Moupila Village & $40.04 \pm 8.58$ & $27.33 \pm 2.69$ & $93.35 \pm 2.96$ \\
\hline Prlvt 9 & Moupila Village & $21.15 \pm 12.5$ & $9.45 \pm 3.61$ & $30 \pm 4.73$ \\
\hline Prlvt 10 & Moupila Village & $21.43 \pm 6.86$ & $24 \pm 2.59$ & $23.67 \pm 6.61$ \\
\hline Prlvt 11 & Moupila Village & $31.28 \pm 13$ & $20.08 \pm 2.95$ & $88.95 \pm 2.95$ \\
\hline Prlvt 12 & Moupila Village & $25.63 \pm 12.16$ & $14.29 \pm 3.38$ & $85.28 \pm 2.99$ \\
\hline Prlvt 13 & Moupila Village & $23.57 \pm 8.64$ & $15.75 \pm 2.98$ & $21.01 \pm 6.47$ \\
\hline Prlvt 14 & Moupila Village & $25.23 \pm 9.69$ & $20.27 \pm 2.76$ & $32.4 \pm 4.46$ \\
\hline Prlvt 15 & Nkoungou Village & $23.28 \pm 10.32$ & $21.61 \pm 2.72$ & $27.37 \pm 5.82$ \\
\hline Prlvt 16 & Nkoungou Village & $18.45 \pm 10.78$ & $11.02 \pm 3.33$ & $21.21 \pm 5.94$ \\
\hline Prlvt 17 & Nkoungou Village & $22.3 \pm 7.46$ & $22.92 \pm 2.60$ & $30.09 \pm 5.29$ \\
\hline Minimum & & $17.36 \pm 10.74$ & $8.68 \pm 3.7$ & $20.89 \pm 5.58$ \\
\hline Maximum & & $40.04 \pm 8.58$ & $27.33 \pm 2.69$ & $93.35 \pm 2.96$ \\
\hline Mean & & $25.14 \pm 10.06$ & $18.16 \pm 2.94$ & $46.15 \pm 4.69$ \\
\hline
\end{tabular}

\footnotetext{
Corresponding author: foxrussellrolph@gmail.com
} 
Results have been compared to other studies worldwide (Table 2)

Table 2. Comparison with other studies worldwide.

\begin{tabular}{|l|l|l|l|c|}
\hline \multicolumn{1}{|c|}{ Country } & ${ }^{\mathbf{2 3 8}} \mathbf{U}(\mathbf{B q} / \mathbf{k g})$ & ${ }^{{ }^{232}} \mathbf{T h}(\mathbf{B q} / \mathbf{k g})$ & $\left.{ }^{\mathbf{4 0}} \mathbf{K} \mathbf{( B q} / \mathbf{k g}\right)$ & Reference \\
\hline Venezuela & $15-37$ & $24-141$ & $325-822$ & {$[1]$} \\
\hline Pakistan & $21-48$ & $22-59$ & $303-945$ & {$[2]$} \\
\hline Algeria & $2-12$ & $72-144$ & $35-1405$ & {$[3]$} \\
\hline Egypt & $5-24$ & $2-102$ & $93-660$ & {$[4]$} \\
\hline Italy & $57-71$ & $73-87$ & $580-760$ & {$[5]$} \\
\hline Ikara, Greece & $8-1049$ & $5-296$ & $238-1439$ & {$[6]$} \\
\hline Congo & $17.36-40.04$ & $8.68-27.33$ & $21.01-117.3$ & Present work \\
\hline
\end{tabular}

\section{2 Radiation hazard parameters}

\section{2. 1 The absorbed dose rates}

Since soils of the study area are used as a building material by the local population (bricks making, ...), they may lead indoor and outdoor radiation exposure as well as the internal and external exposure of inhabitants. The outdoor absorbed dose rate (Dout), allows to assess the outdoor absorbed gamma dose rates in air, due to terrestrial gamma rays, originating from ${ }^{226} \mathrm{Ra},{ }^{232} \mathrm{Th}$ and ${ }^{40} \mathrm{~K}$, located in the soil. In this case, we assume that those radionuclides are equally distributed in ground, and the absorbed dose rate is measured at $1.0 \mathrm{~m}$ above the ground level. The absorbed dose rate (outdoor) was estimated using the following conversion factors 0.427 $\mathrm{nGy} / \mathrm{h}$ per Bq per $\mathrm{kg}$ for ${ }^{226} \mathrm{Ra}, 0.662 \mathrm{nGy} / \mathrm{h}$ per $\mathrm{Bq}$ per $\mathrm{kg}$ for ${ }^{232} \mathrm{Th}$ and $0.043 \mathrm{nGy} / \mathrm{h}$ per Bq per $\mathrm{kg}$ for ${ }^{40} \mathrm{~K}$. The following equation has been used to calculate $\mathrm{D}_{\text {out }}$ according to [9]:

$\mathrm{D}_{\text {out }}(\mathrm{nGy} / \mathrm{h})=0.427 \mathrm{~A}_{\mathrm{Ra}}+0.662 \mathrm{~A}_{\mathrm{Th}}+0.043 \mathrm{~A}_{\mathrm{K}}$

Where $A_{R a}, A_{T h}$ and $A_{K}$ are respectively the activity concentrations of ${ }^{226} \mathrm{Ra},{ }^{232} \mathrm{Th}$ and ${ }^{40} \mathrm{~K}$ defined previously.

In other hand, the use of contaminated soils as building material, increase the internal radiation. Indeed, according to [9], the indoor absorbed dose rates is 1.4 times higher than outdoors.

$$
\mathrm{D}_{\text {in }}(\mathrm{nGy} / \mathrm{h})=1.4 \mathrm{D}_{\text {out }}
$$

Results are displayed in Table 3. Indeed, $\mathrm{D}_{\text {out }}$ and $\mathrm{D}_{\text {in }}$ values varied respectively from 16.79 to $43.43 \mathrm{nGy} / \mathrm{h}$ with mean value of $29.13 \mathrm{nGy} / \mathrm{h}$ and 23,50 to 60,80 $\mathrm{nGy} / \mathrm{h}$ with the mean value of $40,78 \mathrm{nGy} / \mathrm{h}$, relatively low compare to the world values of 60 and $84 \mathrm{nGy} / \mathrm{h}$ respectively [9].

\section{2. 2 The annual effective dose (E)}

The annual effective dose $\mathrm{E}(\mathrm{mSv} / \mathrm{y})$ is estimated from previous doses rate calculated. The following equation proposed by [10] taken into an account outdoor and indoor exposure, has been used to calculate the annual effective dose:

$$
\mathrm{E}(\mathrm{mSv} / \mathrm{y})=\left(\mathrm{D}_{\text {out }} \mathrm{OF}_{\text {out }}+\mathrm{D}_{\text {in }} \mathrm{OF} \text { in }\right) \cdot \mathrm{T} \cdot \mathrm{CF}
$$

In this equation, $\mathrm{OF}_{\text {out }}$ and $\mathrm{OF}_{\text {in }}$ are the outdoor and indoor occupation factors respectively. In the case of lifestyle in Hinda district, people spend most of their times outside than inside of their houses. This affirmative carried out during our sampling period in the study area. It has been noticed that the population are outside all the day: in their fields, in chase of animals, by feeding their cattle, etc and are usually at home on night for eating, sleeping or taking rapidly some tools for works. Therefore, in the present study, $\mathrm{OF}_{\text {out }}$ and $\mathrm{OF}_{\text {in }}$ have been assumed to be $60 \%$ (14h outside) and $40 \%$ ( $10 \mathrm{~h}$ inside). This proposition carried out to adapt the present study to the reality on the spot, contrary to the lifestyle of people in developed countries, where about $80 \%$ of people's times is spent in buildings.

$\mathrm{CF}$ equals to $0.7 \times 10^{-6} \mathrm{~Sv} \mathrm{G} / \mathrm{y}$ is the conversion factor from the absorbed dose in the air to the effective dose received by adults at a height $1 \mathrm{~m}$ above the ground surface and $\mathrm{T}=8760 \mathrm{~h}$ is the time for one year [9].

Results are displayed in Table 3. The values range from 0,12 to $0,31 \mathrm{mSv} /$ year with a mean value of $0.21 \mathrm{mSv} / \mathrm{y}$, less than the maximum value of $1 \mathrm{mSv} / \mathrm{y}$ recommended by [11]. 


\section{2. 3 The radium equivalent activity $\left(R_{\text {aeq }}\right)$}

The radium equivalent activity is assessed to the sum of ${ }^{226} \mathrm{Ra},{ }^{232} \mathrm{Th}$ and ${ }^{40} \mathrm{~K}$ activities, and considered like a common radiological index, because of the non-uniform distribution of radionuclides in the material buildings. The following conversion factors $1 \mathrm{nGy} / \mathrm{h}$ per Bq per $\mathrm{kg}$ for ${ }^{226} \mathrm{Ra}, 1.43 \mathrm{nGy} / \mathrm{h}$ per $\mathrm{Bq}$ per $\mathrm{kg}$ for ${ }^{232} \mathrm{Th}$ and 0.077 $\mathrm{nGy} / \mathrm{h}$ per Bq per $\mathrm{kg}$ for ${ }^{40} \mathrm{~K}$ were used to determine this parameter $[9,12](4)$ :

$$
\text { Raeq }(\mathrm{Bq} / \mathrm{kg})=\mathrm{A}_{\mathrm{Ra}}+1.43 \mathrm{~A}_{\mathrm{Th}}+0.077 \mathrm{~A}_{\mathrm{K}}
$$

Where $\mathrm{Raeq}(\mathrm{Bq} / \mathrm{kg})$ is a radium equivalent activity and $\mathrm{A}_{\mathrm{Ra}}, \mathrm{A}_{\mathrm{Th}}$ and $\mathrm{A}_{\mathrm{K}}$ are the activity concentrations of ${ }^{226} \mathrm{Ra}$, ${ }^{232} \mathrm{Th}$ and ${ }^{40} \mathrm{~K}$ respectively in $\mathrm{Bq} / \mathrm{kg}$.

Results are displayed in Table 3. The values range from 37.12 to $96.08 \mathrm{~Bq} / \mathrm{kg}$ with the mean value of $64.7 \mathrm{~Bq} / \mathrm{kg}$, relatively low compare to the world mean value 370 $\mathrm{Bq} / \mathrm{kg}$ [9].

\section{2. 4 Representative level index (Irr)}

The representative level index IYr is a helpful parameter for material constructions. It allows to identify material that may be hazardous to health when this last one is used for building constructions. I $\mathrm{rr} \leq 1$, corresponds to dose rate $\leq 0.3 \mathrm{mSv} / \mathrm{y}$, whereas $\mathrm{I} \gamma \mathrm{r} \leq 3$, corresponds to dose rate $\leq 1 \mathrm{mSv} / \mathrm{y}$. The following equation has been used to calculate I Ir [13, 14]:

$$
\mathrm{I}_{\mathrm{rr}}=\frac{A_{\mathrm{Ra}}}{150}+\frac{\mathrm{A}_{\mathrm{Th}}}{100}+\frac{A_{K}}{1500}
$$

Where $A_{R a}, A_{T h}, A_{K}$ are the activity concentrations $(\mathrm{Bq} / \mathrm{kg})$ of ${ }^{40} \mathrm{~K},{ }^{226} \mathrm{Ra}$ and ${ }^{232} \mathrm{Th}$, respectively, in the samples.

Results are displayed in the Table 3. The values range from 0.25 to 0.66 with the mean value of 0.44 , less than the unit.

\section{2. 5 Gamma activity index}

The gamma activity index I was estimated to see the level of dangerousness of material buildings used on the population health in the region. It correlates with $\mathrm{I}_{\mathrm{Yr}}$ The following equation has been used to determined I [15] Eq (6):

$$
\mathrm{I}=\frac{A_{R} a}{300}+\frac{A_{T h}}{200}+\frac{A_{K}}{3000}(6)
$$

where $A_{K}, A_{R a}$ and $A_{T h}$ are the activity concentrations $(\mathrm{Bq} / \mathrm{kg})$ of ${ }^{40} \mathrm{~K},{ }^{226} \mathrm{Ra}$ and ${ }^{232} \mathrm{Th}$, respectively, in the samples.

Results are displayed in the Table 3. The values range from 0.13 to 0.33 with a mean value of 0.22 , less than the unit.

\section{2. 6 Hazards indexes}

The hazard index due to internal and external exposure, respectively denoted $\mathrm{H}_{\mathrm{in}}$ and $\mathrm{H}_{\mathrm{ex}}$ from soils of the study area were assessed using models proposed by [16] Eq. (7) and (8). These parameters are determined to assessed the external and internal radiological risks associated with construction materials. The main objective of these parameters is to limit the dose to an equivalent dose of $1 \mathrm{mSv} / \mathrm{y}$. In general, these parameters must not exceed the limit of unity.

$$
\begin{aligned}
\mathrm{H}_{\mathrm{ex}} & =\frac{A_{R a}}{370}+\frac{A_{T h}}{259}+\frac{A_{K}}{4810}(7) \\
\mathrm{H}_{\text {in }} & =\frac{A_{R a}}{185}+\frac{A_{T h}}{259}+\frac{A_{K}}{4810}(8)
\end{aligned}
$$

Where $A_{K}, A_{R a}$ and $A_{T h}$ are the activity concentrations $(\mathrm{Bq} / \mathrm{kg})$ of ${ }^{40} \mathrm{~K},{ }^{226} \mathrm{Ra}$ and ${ }^{232} \mathrm{Th}$, respectively, in the samples.

Results are displayed in Table 3. For $\mathrm{H}_{\mathrm{ex}}$, values range from 0.1 to 0.26 with the mean value of 0.17 , while $H_{\text {in }}$ values range from 0.16 to 0.39 with a mean value of 0.27 , all under the unit.

\footnotetext{
*Corresponding author: foxrussellrolph@gmail.com
} 
Table 3. Calculated radiological indices for the study area.

\begin{tabular}{|l|c|c|c|c|c|c|c|c|}
\hline Sample & $\begin{array}{c}\mathbf{D}_{\text {out }} \\
(\mathbf{n G y / h})\end{array}$ & $\begin{array}{c}\mathbf{D} \text { in } \\
(\mathbf{n G y} / \mathbf{h})\end{array}$ & $\begin{array}{c}\mathbf{E} \\
(\mathbf{m S v} / \mathbf{y})\end{array}$ & $\begin{array}{c}\mathbf{R a} \\
(\mathbf{B q} / \mathbf{k g})\end{array}$ & $\mathbf{I} \mathbf{r}$ & $\mathbf{I}$ & $\mathbf{H}_{\text {ex }}$ & $\mathbf{H}_{\text {in }}$ \\
\hline Prlvt 1 & 16.79 & 23,50 & 0,12 & 37.12 & 0.25 & 0.13 & 0.10 & 0.16 \\
\hline Prlvt 2 & 33.61 & 47,05 & 0,24 & 75.10 & 0.51 & 0.26 & 0.20 & 0.31 \\
\hline Prlvt 3 & 35.54 & 49,75 & 0,25 & 78.10 & 0.55 & 0.27 & 0.21 & 0.31 \\
\hline Prlvt 4 & 35.58 & 49,81 & 0,25 & 78.40 & 0.54 & 0.27 & 0.21 & 0.32 \\
\hline Prlvt 5 & 32.45 & 45,43 & 0,23 & 72.57 & 0.50 & 0.25 & 0.19 & 0.30 \\
\hline Prlvt 6 & 22.81 & 31,93 & 0,16 & 50.90 & 0.35 & 0.17 & 0.14 & 0.21 \\
\hline Prlvt 7 & 26.66 & 37,32 & 0,19 & 59.47 & 0.41 & 0.20 & 0.16 & 0.25 \\
\hline Prlvt 8 & 43.43 & 60,80 & 0,31 & 96.08 & 0.66 & 0.33 & 0.26 & 0.39 \\
\hline Prlvt 9 & 17.79 & 24,90 & 0,13 & 39.27 & 0.27 & 0.13 & 0.11 & 0.17 \\
\hline Prlvt 10 & 29.27 & 40,97 & 0,21 & 65.98 & 0.45 & 0.23 & 0.18 & 0.26 \\
\hline Prlvt 11 & 37.93 & 53,10 & 0,27 & 83.39 & 0.58 & 0.28 & 0.22 & 0.35 \\
\hline Prlvt 12 & 28.19 & 39,46 & 0,20 & 61.51 & 0.30 & 0.21 & 0.16 & 0.26 \\
\hline Prlvt 13 & 24.81 & 34,73 & 0,18 & 55.35 & 0.38 & 0.19 & 0.15 & 0.23 \\
\hline Prlvt 14 & 28.98 & 40,57 & 0,21 & 64.77 & 0.44 & 0.22 & 0.17 & 0.26 \\
\hline Prlvt 15 & 30.57 & 42,79 & 0,22 & 68.46 & 0.47 & 0.23 & 0.18 & 0.28 \\
\hline Prlvt 16 & 19.04 & 26,65 & 0,14 & 42.29 & 0.29 & 0.14 & 0.11 & 0.18 \\
\hline Prlvt 17 & 31.78 & 44,49 & 0,23 & 71.19 & 0.49 & 0.24 & 0.19 & 0.29 \\
\hline Min & 16,79 & 23,50 & 0,12 & 37.12 & 0.25 & 0.13 & 0.10 & 0.16 \\
\hline Max & 43,43 & 60,80 & 0,31 & 96.08 & 0.66 & 0.33 & 0.26 & 0.39 \\
\hline Mean & 29.13 & 40,78 & 0.21 & 64.70 & 0.44 & 0.22 & 0.17 & 0.27 \\
\hline
\end{tabular}

However, results of $\mathrm{D}_{\text {out }}$ have been also compared to other worldwide (Tab. 4).

Table 4. Absorbed dose rates (nGy/h) from different parts of the world.

\begin{tabular}{|l|c|c|}
\hline \multicolumn{1}{|c|}{ Country } & Mean value & Reference \\
\hline Kenya & 69.5 & {$[17]$} \\
\hline Germany & 94 & {$[18]$} \\
\hline Goa Region (India) & 64 & {$[19]$} \\
\hline Japan & 49 & {$[20]$} \\
\hline Kaiga Region (India) & 66 & {$[21]$} \\
\hline Switzerland & 87 & {$[22]$} \\
\hline Turkey & 253 & {$[23]$} \\
\hline Bangalore Region (India) & 73.9 & {$[24]$} \\
\hline Norway & 73 & {$[25]$} \\
\hline Agbabu (Nigeria) & 12.65 & {$[26]$} \\
\hline Bitsichi (Nigeria) & 890 & {$[27]$} \\
\hline South western Nigeria & 60.5 & {$[28]$} \\
\hline South western Nigeria & 95.03 & {$[29]$} \\
\hline Hinda district (Congo) & 29.12 & Present work \\
\hline
\end{tabular}

\section{3 Correlation analysis}

\footnotetext{
* Corresponding author: foxrussellrolph@gmail.com
} 
Correlation analysis was also carried out to determine the mutual relationships and association between pairs of variables through the calculation of the Pearson correlation coefficient. A strong positive correlation among variables indicates similar source and behavior in the environment. Results of the correlation coefficients among all the studied radiological parameters are presented in Table 5.

Table 5. Pearson correlation coefficients among radioactive parameters

\begin{tabular}{|c|c|c|c|c|c|c|c|c|c|c|}
\hline & ${ }^{238} \mathrm{U}$ & ${ }^{232} \mathrm{Th}$ & ${ }^{40} \mathrm{~K}$ & Raeq & Hex & Hin & I $p r$ & D & $\mathrm{Ed}$ & I \\
\hline${ }^{238} \mathrm{U}$ & 1 & & & & & & & & & \\
\hline${ }^{232} \mathrm{Th}$ & 0,62 & 1 & & & & & & & & \\
\hline${ }^{40} \mathrm{~K}$ & 0,77 & 0,37 & 1 & & & & & & & \\
\hline Raeq & 0,83 & 0,91 & 0,65 & 1 & & & & & & \\
\hline Hex & 0,83 & 0,91 & 0,65 & 1 & 1 & & & & & \\
\hline Hin & 0,85 & 0,88 & 0,66 & 0,99 & 0,99 & 1 & & & & \\
\hline $\mathrm{I} \gamma \mathrm{r}$ & 0,79 & 0,92 & 0,56 & 0,96 & 0,96 & 0,95 & 1 & & & \\
\hline $\mathrm{D}$ & 0,84 & 0,90 & 0,68 & 0,99 & 0,99 & 0,99 & 0,96 & 1 & & \\
\hline $\mathrm{Ed}$ & 0,84 & 0,90 & 0,68 & 0,99 & 0,99 & 0,99 & 0,96 & 1 & 1 & \\
\hline I & 0,84 & 0,91 & 0,66 & 0,99 & 0,99 & 0,99 & 0,96 & 0,99 & 0,99 & 1 \\
\hline
\end{tabular}

\footnotetext{
* Corresponding author: foxrussellrolph@gmail.com
} 


\section{Discussion}

The activity concentrations of ${ }^{40} \mathrm{~K},{ }^{238} \mathrm{U}$ and ${ }^{232} \mathrm{Th}$ varied from $21.01 \pm 6.47$ to $117.3 \pm 2.69 \mathrm{~Bq} / \mathrm{kg}, 17.36 \pm 10.74$ to $40.04 \pm 8.58 \mathrm{~Bq} / \mathrm{kg}$ and $8.68 \pm 3.7$ to $27.33 \pm 2.69$ $\mathrm{Bq} / \mathrm{kg}$ respectively.

The mean activity concentrations of ${ }^{238} \mathrm{U}(25.14 \pm 10.06$ $\mathrm{Bq} / \mathrm{kg}),{ }^{232} \mathrm{Th}(18.16 \pm 2.94 \mathrm{~Bq} / \mathrm{kg})$ and ${ }^{40} \mathrm{~K}(46.15 \pm$ $4.69 \mathrm{~Bq} / \mathrm{kg}$ ) in the soil samples were observed to be respectively low compared to the mean world values: ${ }^{238} \mathrm{U}(40 \mathrm{~Bq} / \mathrm{kg}),{ }^{232} \mathrm{Th}(40 \mathrm{~Bq} / \mathrm{kg})$ and ${ }^{40} \mathrm{~K}(420 \mathrm{~Bq} / \mathrm{kg})$, [9].

The low activity concentrations of ${ }^{40} \mathrm{~K}$ in the study area, mainly in the mine, is explained in the fact that Holle potash mine is an underground mine. However, potash ore were mined at about $3 \mathrm{~km}$ under the surface. After the mine flooded in $1977 \mathrm{~s}$, all the mine's surface has been covered by gem salts (Figure 2). And the gem salts are principally composed of Nacl. Considering samples, collected at about $5 \mathrm{~cm}$ above the surface, justify the low activity concentrations of ${ }^{40} \mathrm{~K}$ in the mine. So, no radiological health risks are posed in the study area.

For comparison, the total activity concentration in soil samples in the study area and some other countries worldwide is displayed in Table 2. The mean concentration of ${ }^{40} \mathrm{~K}$ is within the range and lower than most studies reported in Table 2.The mean concentration of ${ }^{40} \mathrm{~K}$ is within the range and lower than most studies. The range of the concentrations of ${ }^{232} \mathrm{Th}$ is almost lower than those of other countries. While, the range of the concentrations of ${ }^{238} \mathrm{U}$ is also lower than those of other countries except for Algeria, Egypt and Venezuela.

The annual effective dose $(0.21 \mathrm{mSv} / \mathrm{y})$ of the present study is lower than those reported by [30] $(0.34 \mathrm{mSv} / \mathrm{y})$ and [31] $(0.239 \mathrm{mSv} / \mathrm{y})$, also under the mean world value. The outdoor absorbed dose rates $(29.13 \mathrm{nGy} / \mathrm{h})$, the indoor absorbed dose rates $(40.78 \mathrm{nGy} / \mathrm{h})$ the radium equivalent activity $(64.7 \mathrm{~Bq} / \mathrm{kg})$, the representative level index (0.44), the gamma activity index (0.22), the external hazard index (0.17), and the internal hazard index (0.27) are under limits [11].

The mean absorbed dose rate values of the present study have been compared to those worldwide (Table 4).It is shown that the mean value of absorbed dose rates in the present study is greater of about twice than that reported by Agbabu (Nigeria) and lower than those reported for Turkey (about nine times), Japan (about twice), Germany (about three times), Goa Region and Kaiga Region in India (about twice), Spain (about twice), Switzerland (about three times), Bangalore Region in India (about three times), Norway (about three times), Bitsichi (about thirty-one times) and in Southwestern in 2008 (about twice) and 2009 (about twice) in Nigeria. These differences are principally due to geological and hydrogeological conditions of different study areas and different conversion factors used. For instance, in the present study following conversion factors were used: $0.427 \mathrm{nGy} / \mathrm{h}$ for ${ }^{226} \mathrm{Ra}, 0.662 \mathrm{nGy} / \mathrm{h}$ for ${ }^{232} \mathrm{Th}$ and 0.043
$\mathrm{nGy} / \mathrm{h}$ for ${ }^{40} \mathrm{~K}$ [9]. While, in the study reported by [29] used [32] for the determination of the absorbed dose rate in the South Western Region in Nigeria, with following conversion factors: $0.043 \mathrm{nGy} / \mathrm{h}$ for ${ }^{40} \mathrm{~K}, 0.427 \mathrm{nGy} / \mathrm{h}$ for ${ }^{226} \mathrm{Ra}$ and $0.666 \mathrm{nGy} / \mathrm{h}$ for ${ }^{232} \mathrm{Th}$.

However, a strong positive correlation coefficient is observed between ${ }^{238} \mathrm{U}$ and ${ }^{232} \mathrm{Th}$, and ${ }^{238} \mathrm{U}$ and ${ }^{40} \mathrm{~K}$ (Table 5). It means that their origins and behaviors are the same in the study area, while weak positive correlation coefficient is observed between ${ }^{232} \mathrm{Th}$ and ${ }^{40} \mathrm{~K}$. This indicates that they may have the same origin but their behaviors in the study area differ. All the three radionuclides have strong positive correlation coefficients with the radiological parameters. This indicates that it exists strong relationship between radionuclides and radiological indices i.e., all the three radionuclides contribute significantly to gamma-ray emission at the sampling points.

\section{Conclusion}

Mean concentrations of natural radionuclides and all calculated radiological parameters are below the recommended level. Correlation analysis shows that it exists a positive correlation between all the three radionuclides, also with radiological parameters. Based on these low levels of natural radioactivity concentrations in the study area, it can be concluded that soils of the study area, pose no radiological health risk to the local population and to visitors. Results of the present study may form the baseline scientific data of external terrestrial gamma-radiation doses and an estimate of radiation exposure to public from soils of the study area.

Acknowledgements: This work was partially funded by the International Atomic Energy Agency (IAEA) through the $\mathrm{PhD}$ Sandwich Programme in the frame of the regional project RAF0052.

\section{References}

[1] Palacios D., Castro D., Perez, Urbani F., Sajo-Bohus L., LaBrecque J., Environmental radioactivity near the central coast of Venezuela and its radiological impact. Jour. Radioanal. Nucl. Chem., v.241, pp.69-73 (1998).

[2] Tahir S., Jamil K., Zaidi J., Arif M., Ahmed N., Ahmad S., Measurements of activity concentrations of naturally occurring radionuclides in soil samples from Punjab Province of Pakistan and assessment of radiological hazards, Radiat. Prot. Dosimetry, v. 113(4), pp.421-427 (2005).

\footnotetext{
Corresponding author: foxrussellrolph@gmail.com
} 
[3] Baggoura B., Noureddine A., Benkrid M., Level of natural and artificial in Algeria radioactivity. Appld. Radiat. Isot., v.49(7), pp.867-873 (1998).

[4] Sroor A., El-Bahi S., Ahmed F, Abdel-Haleem A., Natural radioactivity and radon exhalation rate of soil in southern Egypt, Appl. Radiat. Isot., v.55, pp.873-879 (2001).

[5] Bellia S., Brai M., Hauser S., Puccio P., Rizzo A., Natural radioactivity in a volcanic island Ustica, Southern Italy. Applied. Radiat. Isot., v.48, pp.287293 (1997).

[6] Florou H., Trabidou G., and Nicolaou G., An assessment of the external radiological impact in areas of Greece with elevated natural radioactivity. Jour. Environ. Radioact., v.93, pp.74-83 (2007).

[7] Veiga M., Baker R., Protocols for environmental and health assessment of mercury released by artisanal and small-scale gold miners. Vienna: GEF/UNDP/UNIDO (2004).

[8] British standard, Measurement of radioactivity in the environment-soil. BS ISO18589 - 1: 2005 (2005).

[9] UNSCEAR, Sources and effects of ionizing radiation. United Nations scientific committee on the effects of atomic radiation. New York, USA: United Nations Publication (2000).

[10] Mahmoud P.A., Aghajani M., Nabipour I., Assadi M., Annual effective dose from environmental gamma radiation in Bushehr city. J. Environ. Health Sci. Eng. 12: 4 (2014).

[11] ICRP, 1990 Recommendations of the International Commission on Radiological Protection. ICRP. Ann. ICRP 21,1-3 (1991).

[12] Beretka J., Matthew P., Natural radioactivity of Australian building materials, industrial waste and by-products. Health Phys. 48, 87-95 (1985).

[13] NEA-OECD, Exposure to radiation from natural radioactivity in building materials. In: Report by the group of experts of the OECD Nuclear Energy Agency (NEA), Paris (1979).

[14] Higgy R., El-Tahawy M., Abdel-Fattah A., AlAkabawy V., Radionuclide content of building materials and associated gamma dose rates in Egyptian dwellings. J Environ Radioact 50:253261 (2000).

[15] European Commission, European Commission report on radiological protection principles concerning the natural radioactivity of building materials, Radiat. Protect. 112 (1999).

[16] Krieger V., Radioactivity of construction materials, BetonwerkFertigteil Tech. 47:468-473 (1981).

[17] Mustapha A., Patel J., Rathore I., Assessment of human exposure to natural sources of radiation in Kenya, Radiat. Prot. Dosim. 82(4):285-292 (1999).

[18] Ohlsen H., Determination of the mean population burden from natural external radiation in the German Democratic Republic. SZE-14/69 and AEC-tr-7216 (1971)

[19] Avadhani D., Mahesh H., Somashekarappa H., Karunakara N., Narayana Y., Siddappa K., Natural radioactivity in the environment of Goa of south west coast of India. J Radiat Protect Environ 24 (Suppl):136-142 (2001).

[20] Abe S., Fujitaka K., Natural radiation in Japan. In: Gesell TF, Lowder WM (eds) Natural radiation environment III, vol 2. USDOE, CONF-780422. Technical Information Centre, Oak Ridge, TN, pp 1034-1048 (1980).

[21] Karunakara N., Somashekarappa H., Avadhani D., Mahesh H., Narayana Y., Siddappa K., ${ }^{226} \mathrm{Ra},{ }^{232} \mathrm{Th}$ and ${ }^{40} \mathrm{~K}$ distribution in the environment of Kaiga of south west coast of India. Health Phys. 80:470-476 (2001).

[22] Herbst W., Investigation of environmental radiation and its variability. In: Adam JAS, Lowder W.M. (eds) Natural radiation environment. University of Chicago Press, Chicago, pp 781-796 (1964).

[23] Merdanoglu B., Altinsoy N., Radioactivity concentrations and dose assessment for soil samples from Kestanbol granite area Turkey. Radiat. Protect. Dosim. 121:399-405 (2006).

[24] Shiva Prasad N., Nagaiah N., Ashok G., Karanukara N., Concentrations of ${ }^{226} \mathrm{Ra},{ }^{232} \mathrm{Th}$ and ${ }^{40} \mathrm{~K}$ in the soils of Bangalore Region, India. Health Phys. 94(3):264-271 (2008).

[25] Stranden E., Some aspects on radioactivity of building materials, Phys. Nor. 8:167-173 (1976).

[26] Isinkaye M., Radiometric assessment of natural radioactivity levels of bituminous soil in Agbabu, southwest Nigeria. Radiat Meas. 43:125-128 (2008).

[27] Jibiri N., Farai I., Alausa S., Activity concentrations of ${ }^{226} \mathrm{Ra},{ }^{228} \mathrm{Th}$ and ${ }^{40} \mathrm{~K}$ in different food crops from a high background radiation area in Bitsichi, Jos Plateau, Nigeria. Radiat. Environ Biophys. 46:5359 (2007).

[28] Ajayi O., Ibikunle S., Ojo T., An assessment of natural radioactivity of soils and its external radiological impact in southwestern Nigeria. Health Phys 94(6):558-566 (2008).

[29] Ajayi O., Measurement of activity concentrations of ${ }^{40} \mathrm{~K},{ }^{226} \mathrm{Ra}$ and ${ }^{232} \mathrm{Th}$ for assessment of radiation hazards from soils of the southwestern region of Nigeria, Radiat Environ Biophys, 48:323-332, DOI 10.1007/s00411-009-0225-0 (2009).

[30] Dallou G., Ngoa E., Ndjana Nkoulou II J., Saïdou, Tchuente Siaka Y., Bongue D., Kwato Njock M., NORM Measurements and Radiological Hazard Assessment in the Gold Mining Areas of Eastern Cameroon, Radiation Environment and Medicine 2017, Vol.6, No.1 22-28 (2016).

[31] Raghavendra T., Vishwaprasad G., Kalyani T., Vijayalakshmi V., Himabindu J., Arunachalam P., Padmasavithri, Vinod Kumar R., Tripathi., Assessment of Natural Radioactivity in Soils around the Proposed Uranium Mining Site of Lambapur - Peddagattu and Seripally, India, JOURNAL GEOLOGICAL SOCIETY OF INDIA, Vol.93, pp.223-227 (2009).

*Corresponding author: foxrussellrolph@gmail.com 
[32] United Nations Scientific Committee on Effects of Atomic Radiation (UNSCEAR) Sources and effects of ionizing radiation. UN, New York (1998).

*Corresponding author: foxrussellrolph@gmail.com 